\title{
MANAGEMENT OF THE PACKAGING WASTE IN COMPANIES IN POLAND
}

\begin{abstract}
Most of the products available on the market are sold in packagings. Majority of people do not realize, however, that these packagings, after being emptied, become waste. Legislation in force in Poland requires proper management of such waste. In the article the definition of packaging in accordance with the Act on packaging and packaging waste was presented. The most important function of packagings from the point of view of a customer were described. Then the concept of packaging waste was defined and the basic rules on the management of such waste were presented.
\end{abstract}

Key words: packaging, environment protection, packaging waste, sustainable development

\section{Introduction}

Many products that we find in everyday life are hard to be imagined without the packaging. Every man's life is inextricably linked with any kind of bottles, cartons, cans or bags. They are saturated with colour or grey, with a highly varied size and shape in the shops, they attract our attention directing it to the product.

Changing the economic system, the free market, competition, business of the company oriented on customer service made that the packaging is no longer seen as for the protection and provision of basic information about the product. The packaging is an integral part of the marketing strategy, is an important element of the market communications.

\footnotetext{
${ }^{1}$ Dr inż., Czestochowa University of Technology, Faculty of Management, Institute of Production Engineering, e-mail: manuela@gazeta.pl

${ }^{2}$ Ing. PhD., Institute of Safety, Environmental and Quality, Faculty of Materials Science and Technology in Trnava, Slovak University of Technology in Bratislava, Trnava, Slovak Republic, e-mail: bkatarina.skurkova@stuba.sk
} 
It is used as part of the promotional campaign of the product and sales activation factor. For small companies that cannot afford expensive advertising campaigns, the packaging is the only transfer of information about the product.

Each person generates various types of waste. After some time also the packaging becomes waste. In the sphere of packaging we should also be aware of the concept of sustainable development. The sustainable development of the Earth is a development that meets the basic needs of all human beings and which conserve, protect and restore the health and integrity of the Earth's ecosystem, without compromising the ability of future generations to meet their own needs and without going over the limits of long term capacity of the earth`s ecosystem (WORLD COMMISSION ON ENVIRONMENT AND DEVELOPMENT). This means that the companies not only should be interested in what happens to the packaging, in which they sells their products to customers, but also how to make these packages to be re-use in the future.

So the waste management, including the management of packaging waste, has become an important element of business management and requires a modern approach to the formation of packaging waste. Proenvironmental management of waste, including packaging waste, becomes very fashionable in the field of business and life.

The aim of this article is to introduce the concept of packages and their functions and to provide basic legislations on packaging and packaging waste in Poland.

\section{Definition of the packaging}

The term package is defined in the Act on packaging and packaging waste. According to this Act the package is " products placed on the market, made of any materials, intended for the storage, protection, transport, delivery or presentation of any product, from raw materials to already processed goods" (USTAWA O OPAKOWANIACH I ODPADACH 
OPAKOWANIOWYCH). So understood packaging according to this Act includes: (USTAWA OPAKOWANIACH I ODPADACH OPAKOWANIOWYCH):

- packaging unit, for transmitting the product to the user in the place of purchase, including also consumption product, such as disposable dishes,

- multipacks containing multiple unit packages of products, regardless of whether they are transmitted to users, or are transmitted to selling points, that can be removed from the product without compromising its features,

- transport packaging, used to transport products in packaging unit or multipacks in order to prevent damage, with the exception of containers for transport by road, rail, water or air.

To pack fulfilled all its functions, we should be aware of the appropriate level of quality of the packaging. As it is defined in ISO 8402, quality packaging is ,set of characteristics, parameters characterizing the packaging associated with its ability to meet the needs of buyers and users". This quality can be described by the following parameters (ISO 8402):

- natural and technical parameters: design, packaging design, quality materials, safety features, mechanical strength;

- aesthetic parameters: colour, graphics and illustration, lettering, shape, relations of mutual distribution patterns and inscriptions;

- ergonomic parameters: ease of transfer from the shop to home, adjust the dimensions of the storage in the home, ease of opening and closing again, the ease of extracting the contents, the most convenient dosage form (aerosols, packaging batch, tubes);

- ecological parameters: ability to biochemical degradation of the material, time degradation, the possibility of re-processing, the possibility of multiple use.

Most products on the market are placed for sale in packs. These packages are important due to their basic functions: protective, informational, promotional-advertising, environmental and qualitative. Nowadays the package is treated as an integral part of marketing strategy 
of company, is used as part of a campaign of product promotion and sales activation factor.

Protective function means securing of the quality of the finished product during transport or storage, in the case of dangerous products it protects the environment against their effects. Information function is not only placing the label and brand garments as part of the layout, but also the basic data of the product and the manufacturer. Appropriately designed and labelled packaging affects the attitude and conduct of customers, and it can persuade them to buy the product, hence the promotion-advertising function. Qualitative function is important for example due to the sale of luxury goods. The packaging is made of good materials, with interesting colours, is durable, and emphasizes the high level of product. However, ecological function means the possibility of recycling of the packaging, which indicates that it is environmentally friendly (KONSTANCIAK M., UlEWICZ R., GĘSIARZ O. 2010).

\section{Packaging waste}

According to the Act on packaging and packaging waste by packaging waste can be understood "all packaging including reusable packaging withdrawn from the re-use, constitute waste within the meaning of the waste legislation, with the exception of waste generated in the production of packaging" (USTAWA O OPAKOWANIACH I ODPADACH OPAKOWANIOWYCH).

To reduce the impact of packaging on the environment, the manufacturer according to the Act should remember about few rule (USTAWA O OPAKOWANIACH I ODPADACH OPAKOWANIOWYCH):

- The volume and weight of packaging should be limited to the minimum required to fulfil the functions of the packaging.

- Packaging should be designed and executed in a way that allows their re-use and recycling later, and if this is not possible, at least recycling, and if this is not possible, another form of recovery (Figure 1). 
- Packaging should contain the smallest possible amount of the substance posing threat to the life or health of humans and the environment.

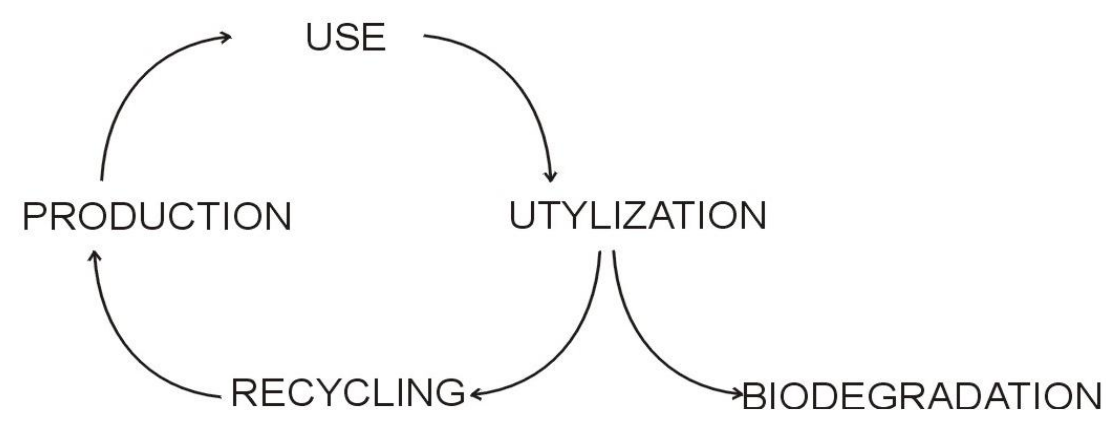

Fig. 1. The environmental-oriented production process.

Source: http://projekttechnologiczny.blogspot.com/2009/06/cykl-zycia-produktu-zamknie ty-obieg.html

To avoid a large amount of packaging waste, reusable packaging should be used. Also this term is defined in the Act. Re-use is understood as "any operation in which packaging conceived and designed for at least two applications is reused for the same purpose for which it was originally intended" (USTAWA O OPAKOWANIACH I ODPADACH OPAKOWANIOWYCH).

Logistics of reusable packaging is becoming more and more popular. Disposable containers most often used in trade, transport, manufacture or storage of product, produce consistently high costs associated with their acquisition, disposal and forwarding. Such packaging has also a greater impact on the environment.

Packaging waste, according to the definition, are postconsumer packaging, which have passed a product trade cycle. In Figure 2 the formation of packaging waste and ways of dealing with it are presented. In this Figure also standards connected with packaging waste are included. 


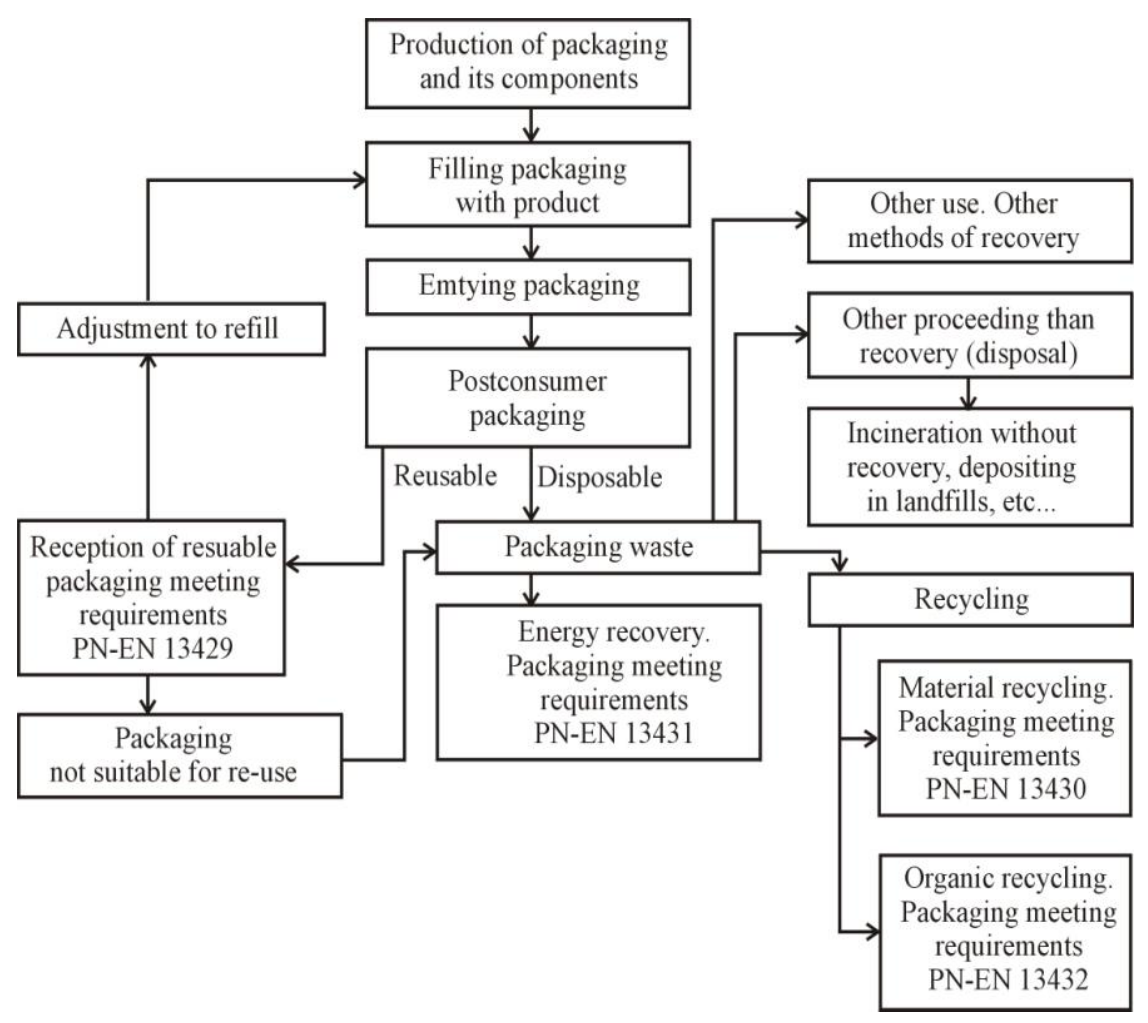

Fig. 2. Schematic of waste packaging formation and handling them. Source: ŻAKOWSKA H. 2005

\section{Packaging waste categories}

There are many types of packaging. These types affect the fact in which waste group of individual packaging should be included. This division is located in the Regulation of the Minister of Environment on waste and European waste catalogue and hazardous waste list. Waste packaging are marked with code 1501 (Tab. 1). In Table 2 list of typical packages in main groups was presented. 
Table 1. Types of packaging waste by waste catalogue

\begin{tabular}{|l|l|}
\hline \multicolumn{1}{|c|}{ Code } & \multicolumn{1}{|c|}{ Type of waste } \\
\hline 1501 & $\begin{array}{l}\text { Packaging (including separately collected municipal packaging } \\
\text { waste) }\end{array}$ \\
\hline 150101 & Paper And Cardboard Packaging \\
\hline 150102 & Plastic Packaging \\
\hline 150103 & Wooden Packaging \\
\hline 150104 & Metallic Packaging \\
\hline 150105 & Composite Packaging \\
\hline 150106 & Mixed Packaging \\
\hline 150107 & Glass Packaging \\
\hline 150109 & Textile Packaging \\
\hline 150110 & $\begin{array}{l}\text { Packaging Containing Residues Of Or Contaminated By Dangerous } \\
\text { Substances }\end{array}$ \\
\hline 150111 & $\begin{array}{l}\text { Metallic Packaging Containing A Dangerous Solid Porous Matrix } \\
\text { (For Example Asbestos), Including Empty Pressure Containers }\end{array}$ \\
\hline
\end{tabular}

Source: ROZPORZADZENIA MINISTRA ŚRODOWISKA W SPRAWIE KATALOGU ODPADÓW; EUROPEAN WASTE CATALOGUE AND HAZARDOUS WASTE LIST

Table 2. List of typical packages and their components in different material groups

\section{Wood, materials made from wood and other natural materials:}

Barrel, frame, basket, box, tray, chest and case (e.g. plating of veneer, plywood, fibreboard, etc.), partial packaging, pallet, fulfilment of voids in packages (e.g. wood wool), interior fittings, inserts , grilles, dividers, etc. the closure of cork, jute and cotton bag and sack, wrapping and netting made of natural materials.

\section{Paper and paperboard:}

Carton box, cardboard box, corrugated board box, solid board box, cardboard tray, paperboard tray, pulp tray, bag or paper bag, paper sack (including with 
insert barrier), cardboard elements rolling drums and other containers in the shape of a tube, sachet, wrapping, equipment of packaging interior, insert, spacer, grilles, filling voids in boxes, etc., labels.

\section{Glass:}

Balloon, bottle, vial, jar, aerosol packaging, cosmetic and pharmaceuticals packaging.

Metal:

Aerosol packaging ( $\mathrm{Al}$, sheet steel), bubble, drum, bottle, cylinder gases (with a capacity up to $80 \mathrm{dm}^{3}$ ), hobbock, canister, jug, box, food and beverage can (aluminium and steel), tray of aluminium foil, aluminium tube, bucket and small bucket, pallet, caps and other closures (e.g., aluminium lids for cups, etc.).

\section{Plastic:}

Ampoule, bubble, barrel, bottle, vial, canister, cup, basket, box, jar, case, tray, bag (e.g., foil of laminate involving two or more plastics, foamed foil, etc.), tube (example of homogeneous plastic laminate with the participation of two or more plastics), bucket and small bucket, a bag of foil, packaging and other packaging elements thermo-formed of foil, hood foil, label, sleeve acting as a label, etc., from wrapping foil (including stretch and shrink foil), the moulding of foamed PS and other fill with foam plastic bag and mesh woven and knitted tapes polyolefin liner, spacer, and other packaging equipment, nut, other closures, applicator and dispenser large bulk container (IBC).

\section{Composite Packaging:}

Box of laminate ,cardboard / plastic / aluminium foil, laminated cardboard box / plastic sachet and pouch laminates involving aluminium foil or metallized films, laminated paper bag / plastic bag with laminate paper / aluminium foil bag, laminate paper / plastic / aluminium foil, laminate pouch with plastic / aluminium foil, laminate tube of plastic / aluminium foil blister pack, packaging and skin pack (if it is combined with other materials, such as cardboard), packing bag in box and a paper bag with insert barrier (if not, you can manually separate the different materials) label laminate paper / plastic etc.

Source: ŻAKOWSKA H. 2005 


\section{Summary}

Suitable packaging waste management will reduce its number in the environment and save resources of the natural environment (Konstanciak A., Pustejovska P. 2013; Kardas E., Brozova S. 2013; INGALDI M., JURSOVA S. 2013). We should note that this waste management is connected only with companies. Also users of packaged products should pay attention to what they buy. A simple example is to have a reusable shopping bag and do not use every time plastic bags; to buy drinks in returnable bottles, because unfortunately in Poland it is very rarely used. Perhaps an increase in demand for the products in packaging which reuse or recycling is possible, will force manufacturers to change their approach to this topic.

\section{Bibliography}

1. European waste catalogue and hazardous waste list. Valid from 1 January 2002. Environmental Protection Agency.

2. http://projekttechnologiczny.blogspot.com/2009/06/cykl-zycia-produktuzamkniety-obieg.html (4.02.2013).

3. Ingaldi M., Jursova S. Economy and Possibilities of Waste Utilization in Poland. [in:] METAL 2013. $22^{\text {nd }}$ International Conference on Metallurgy and Materials. Conference Proceedings. May 15th - 17th 2013, Brno, Czech Republic. TANGER Ltd. Ostrava.

4. ISO 8402.

5. Kardas E., BROzova S. 2013. Situation in Waste Treatment in Poland. [in:] METAL 2013. 22 ${ }^{\text {nd }}$ International Conference on Metallurgy and Materials. Conference Proceedings. May 15th - 17th 2013, Brno, Czech Republic. TANGER Ltd. Ostrava.

6. Konstanciak A., Pustejovska P. 2013. Ecological Possibilities of Waste Utilization in Metallurgical Processes. METAL 2013. $22^{\text {nd }}$ International Conference on Metallurgy and Materials. Conference Proceedings. May 15th - 17th 2013, Brno, Czech Republic. TANGER Ltd. Ostrava. 
7. Konstanciak M., Ulewicz R., GęSiarz O. 2010. Chapter 10. Analysis of Influence of Production Process on Quality of Paperboard Packagings. [in:] Engineering and Quality Production. S.Borkowski, E.B.Tsoy (ed.), Pub. Yurii V. Makovetsky, Dnipropetrovsk, p.118-133.

8. Rozporządzenia Ministra Środowiska z 27 września 2001 r. w sprawie katalogu odpadów (DzU nr 112, poz. 1206, ze zm.).

9. Ustawa $\mathrm{z}$ dnia 11 maja 2001 roku o opakowaniach i odpadach opakowaniowych (DzU nr 63, poz. 638).

10. World commission on environment and development. "our common future, Chapter 2: towards sustainable development". Un-documents.net. Retrieved 2011-09-28.

11. ŻAKOWSKA H. 2005. Recykling odpadów opakowaniowych. Warszawa. 